\title{
Clinical Pharmacokinetics of Caffeine in Korean Preterm Infants with Apnea of Prematurity
}

Myung Seop Lim, M.D., Mi Jeong Son, M.D.*, Jung Eun Shin, M.D., Soon Min Lee, M.D., Ho Sun Eun, M.D., Min Soo Park, M.D., Kook In Park, M.D., and Ran Namgung, M.D.

Departments of Pediatrics and Pharmacology*, Yonsei University College of Medicine, Seoul, Korea

\section{ABSTRACT}

Purpose: Caffeine shows wide interindividual pharmacokinetic (PK) variation, and therapeutic drug monitoring (TDM) may be needed. The PK profile of caffeine in Korean preterm neonates was investigated, and factors influencing the clearance of caffeine were analyzed.

Methods: Fifty-nine preterm neonates receiving caffeine for apnea of prematurity were enrolled in the study (gestational age, 29.5 \pm 2.2 weeks and birth weight [BW], $1,318 \pm 358 \mathrm{~g})$. Caffeine $(20 \mathrm{mg} / \mathrm{kg}$ ) was intravenously administered to each neonate as a loading dose, followed by a maintenance dose of 5-10 mg/kg/d. A total of $190 \mathrm{se}-$ rum concentrations were measured for population $\mathrm{PK}$ analysis and modeling using nonlinear mixed-effects model $\left(\mathrm{NONMEM}^{\circledR}\right)$ software.

Results: The mean serum concentration of caffeine was $15.4 \pm 4.5 \mathrm{mg} / \mathrm{L}$ (range 7.8$33.0 \mathrm{mg} / \mathrm{L}$ ). High serum concentrations ( $>20 \mathrm{mg} / \mathrm{L}$ ) were noted in 36 samples $(29 \%)$. At the first measurement of serum caffeine, the mean postmenstrual age was $33.9 \pm 2.3$ weeks, mean BW was $1,802 \pm 471 \mathrm{~g}$, mean duration of treatment was $7.4 \pm 9.4$ days, and mean sampling time after the last dose was $21.8 \pm 2.1$ hours. In the population PK analysis, the clearance was $0.033 \mathrm{~L} / \mathrm{h}$ and volume of distribution was $0.371 \mathrm{~L}$. Typical clearance was calculated as $0.0293 \times(\mathrm{BW} / 70)^{1.33}$. Among the subjects receiving 5 $\mathrm{mg} / \mathrm{kg} / \mathrm{d}$ caffeine, the most significant risk factor associated with high serum concentrations $(>20 \mathrm{mg} / \mathrm{L})$ was low BW $(P=0.024)$.

Conclusion: BW was the only covariate that influenced caffeine clearance in preterm neonates. Preterm neonates with low BW should be carefully monitored for apnea and adverse reactions in addition to undergoing TDM.

Key words: Apnea of prematurity, Caffeine, Clearance, Pharmacokinetics

\section{INTRODUCTION}

Caffeine is a methylxanthine that acts as a nonspecific inhibitor of adenosine receptors and is used to wean patients from ventilatory support or as a treatment for apnea ${ }^{1)}$. Premature neonates receive a loading dose of $20-80 \mathrm{mg} / \mathrm{kg}$ in the initial 30 minutes, followed
Received: 4 October 2016

Revised: 25 October 2016

Accepted: 25 October 2016

Correspondence to: Soon Min Lee Department of Pediatrics, Yonsei University College of Medicine, Severance Children's Hospital, 50 Yonsei-ro, Seodaemun-gu, Seoul 03722, Korea

Tel: +82-2-2019-3350

Fax: +82-2-3461-9473

E-mail: smlee@yuhs.ac

Copyright(c)

By Korean Society of Neonatology.

All right reserved.

This is an Open-Access article distributed under the terms of the Creative Commons Attribution Non-Commercial License (http://creativecommons.org/licenses/ by-nc/4.0), which permits unrestricted non-commercial use, distribution, and reproduction in any medium, provided the original work is properly cited. 
by a maintenance dose of $5-20 \mathrm{mg} / \mathrm{kg} / \mathrm{d} 24$ hours later ${ }^{2,3}$. The therapeutic dose range is $8-20 \mu \mathrm{g} / \mathrm{mL}$, with toxic effects occurring at doses exceeding $20 \mu \mathrm{g} / \mathrm{mL}^{4}$. Caffeine interacts with drugs metabolized by the cytochrome P450 (CYP) 1A2 enzyme and is eliminated by renal excretion ${ }^{4)}$. Therefore, caffeine pharmacokinetics (PK) may vary in neonates.

The PK profile of caffeine in neonates is characterized by a volume of distribution of $0.8-0.9 \mathrm{~L} / \mathrm{kg}$, which is larger than that of children or adults ${ }^{4,5}$. In addition, the half-life of caffeine in neonates is approximately 72-96 hours, which is longer than that of adults, and is further prolonged with decreased renal function. The kidney is the main pathway of caffeine clearance in neonates; thus, newborns have lower clearance rates than children or adults. The population PK data on neonates, especially premature neonates, have been reported for Chinese, Malaysian, and Caucasian populations; however, no population PK data on Koreans have been analyzed.

There are relatively fewer reports of the adverse effects of caffeine than there are for other drugs used for apnea treatment. Irritability, restlessness, jitteriness, and tachycardia can occur owing to central nervous system (CNS) and cardiovascular stimula$\operatorname{tion}^{6-8)}$. An increase in the caffeine levels in the body increases its potency and toxicity accordingly ${ }^{9)}$. Therefore, when caffeine is administered to premature neonates with unstable metabolism, therapeutic drug monitoring (TDM) is indispensable. This study analyzes the population PK, including serum concentration in preterm neonates who received caffeine for apnea of prematurity, and the factors affecting serum caffeine levels.

\section{MATERIALS AND METHODS}

\section{Patients}

The data were obtained retrospectively from medical records and routine caffeine monitoring of 57 hospitalized neonates (34 female and 23 male neonates) in the neonatal intensive care unit of Severance Children's Hospital from December 2012 to July 2013, using 190 caffeine measurements. The covariate data collected for each patient included sex, birth weight (BW), current weight, birth height, gestational age (GA), postnatal age, postconceptional age, ventilator care, oxygen care, and Apgar score.

The accurate dosing history including date, dose, and route of administration was collected. The typical loading and main- tenance doses of caffeine citrate administered intravenously were 20 and $5 \mathrm{mg} / \mathrm{kg}$ once daily, respectively. However, because of the clinical condition of the neonates, the maintenance caffeine dose ranged from 5 to $10 \mathrm{mg} / \mathrm{kg}$ once daily. The exclusion criteria were major congenital abnormalities, blood cultureproven sepsis, major neurological conditions, liver or renal disorders, or term neonates. The study protocol was approved by the Institutional Review Board of Yonsei University Severance Hospital. The requirement for informed consent was waived because the study was conducted retrospectively.

\section{Serum sampling and analysis}

Actual sampling and treatment times were recorded by a nurse on a data sheet and were checked independently. The serum caffeine concentrations were assayed by chromatography/ mass spectrometry (MS) using an API 4000TM liquid chromatography-tandem MS (LC-MS/MS) system (Applied Biosystems, Foster City, CA, USA). The working assay range was $0.2-50 \mathrm{mg} /$ $\mathrm{L}$, and the inaccuracy and between-day and within-day variance were $<10 \%$ across this range. Samples containing $>20 \mathrm{mg} / \mathrm{L}$ caffeine were diluted in drug-free serum and re-assayed.

\section{PK model}

The concentration time course of caffeine was described using a one-compartment model with either zero- or first-order (infusion vs. oral) absorption and first-order elimination, assuming a permanent non-steady-state condition. The modeling was performed using non-linear mixed-effects model software (NONMEM, version 5.1.1, Globomax LLC, Hanover, MD, USA). The influence of mean-centered covariates was evaluated by adding these to the base model, and in turn, noting the changes in the objective function value (OFV). The inclusion of a covariate was considered to have improved the fit of the data to the model if there was a decrease in the OFV. The differences between a pair of OFV values when a covariate was included (full model) and excluded (nested reduced model) were tested for significance ( $a=0.01$ ) using the $\chi^{2}$ statistic with 1 degree of freedom.

\section{Statistical analysis}

The continuous variables were presented as means \pm standard deviation (SD) and were compared using Student's $t$-test. The categorical variables were presented as percentages and frequencies and compared using the chi-square or Fisher's exact test. The risk factors were analyzed using multivariable linear 
regression analysis adjusted for GA and BW to estimate the odds ratios (ORs) with $95 \%$ confidence intervals (CIs). A $P<0.05$ was considered statistically significant.

\section{RESULTS}

The patient characteristics are described in Table 1 . The results of blood chemistry at the time of caffeine level measurement showed parameters within normal limits as follows. The blood urea nitrogen (BUN) was $7.1 \pm 5.4 \mathrm{mg} / \mathrm{dL}$; creatinine, $0.4 \pm 0.3$ $\mathrm{mg} / \mathrm{dL}$; aspartate transaminase (AST), 28.1 $\pm 29.0 \mathrm{IU} / \mathrm{L}$; alanine transaminase (ALT), $14.8 \pm 21.5 \mathrm{IU} / \mathrm{L}$; albumin, $3.2 \pm 0.3 \mathrm{~g} / \mathrm{dL}$; and the C-reactive protein was $1.8 \pm 3.8 \mathrm{mg} / \mathrm{L}$ (Table 2 ). The mean caffeine concentration was $15.4 \pm 5.0 \mathrm{mg} / \mathrm{L}$, and the distribution of serum caffeine levels is shown in Figure 1, with different shapes depicting data for different therapeutic doses. The sample analysis that showed toxicity potential (with serum caffeine levels $>20$ $\mathrm{mg} / \mathrm{L}$ ) indicated that $6(4.5 \%), 7$ (41.2\%), and 23 (60.5\%) of such samples were associated with $5,7.5$, and $10 \mathrm{mg} / \mathrm{kg}$ maintenance doses, respectively. When analyzing samples with serum caffeine levels <20 mg/L, 129 (95.5\%), 10 (58.8\%), and 15 (39.5\%) samples were associated with $5,7.5$, and $10 \mathrm{mg} / \mathrm{kg}$ maintenance doses, respectively. The overall drug concentration depended on the

Table 1. Characteristics of Study Patients

\begin{tabular}{|c|c|c|}
\hline Characteristic & Mean $\pm S D$ & Range \\
\hline Number of Patients, $n$ & 57 & \\
\hline Male, $\mathrm{n}$ & 23 & \\
\hline Gestational age (wks) & $29.49 \pm 2.22$ & 24.4-33.6 \\
\hline Postconceptional age (wks) & $33.94 \pm 2.28$ & 27.6-39.3 \\
\hline Postnatal age $(\mathrm{d})$ & $36 \pm 23$ & $5-89$ \\
\hline Birth weight (g) & $1,318 \pm 358$ & $530-2,210$ \\
\hline Current weight (g) & $1,802 \pm 471$ & $770-2,995$ \\
\hline Birth height $(\mathrm{cm})$ & $38.93 \pm 3.56$ & $29.5-44$ \\
\hline Apgar score - 1 min & $4.05 \pm 1.19$ & $2-7$ \\
\hline Apgar score - 5 min & $6.12 \pm 1.33$ & $3-10$ \\
\hline Ventilator care $(\mathrm{d})$ & $18.14 \pm 23.10$ & $3-10$ \\
\hline Oxygen care $(\mathrm{d})$ & $42.97 \pm 30.32$ & $1-133$ \\
\hline Number of Samples, $n$ & 190 & \\
\hline Sample time after medication (h) & $21.8 \pm 2.1$ & $12-24$ \\
\hline Caffeine dose (mg/kg) & $6.2 \pm 2.0$ & \\
\hline $5 \mathrm{mg} / \mathrm{kg}, \mathrm{n}(\%)$ & $135(71 \%)$ & \\
\hline $7.5 \mathrm{mg} / \mathrm{kg}, \mathrm{n}(\%)$ & $17(9 \%)$ & \\
\hline $10 \mathrm{mg} / \mathrm{kg}, \mathrm{n}(\%)$ & $38(20 \%)$ & \\
\hline
\end{tabular}

Plus minus values are mean \pm SD. dose administered, but varied within the same dose.

In the case of the $5 \mathrm{mg} / \mathrm{kg}$ administration group, the 6 and 129 samples with serum caffeine levels $>20$ and $<20 \mathrm{mg} / \mathrm{L}$ (high and normal concentration groups), respectively, were compared. The average BWs in the normal and high concentration groups were $1,784 \pm 466 \mathrm{~g}$ and $1,350 \pm 332 \mathrm{~g}$, respectively, which differed significantly ( $P=0.026$, Table 3 ). No significant differences were observed in GA (28.9 and 28.8 weeks for normal and high concentration groups, respectively, $P=0.876$, Table 3 ), postnatal age, birth weight, and Apgar score. In the univariate and multiple linear regression analyses (Table 4), the BW was a significant parameter $(P=0.024)$, whereas the GA, postconceptional age, and Apgar score were not significant. The PK parameters determined were clearance $(0.033 \mathrm{~L} / \mathrm{h})$, the volume of distribution $(0.371 \mathrm{~L})$,

Table 2. Laboratory Data

\begin{tabular}{lcc}
\hline & Mean \pm SD & Range \\
\hline BUN (mg/dL) & $7.1 \pm 5.4$ & $1.0-35.0$ \\
Creatinine (mg/dL) & $0.4 \pm 0.3$ & $0.2-3.2$ \\
AST (IU/L) & $28.1 \pm 29.0$ & $11-377$ \\
ALT (IU/L) & $14.8 \pm 21.5$ & $2-258$ \\
Albumin (g/dL) & $3.2 \pm 0.3$ & $2.3-4.0$ \\
CRP (mg/L) & $1.8 \pm 3.8$ & $0.3-27.4$ \\
\hline
\end{tabular}

Normal range of CRP is $0-8 \mathrm{mg} / \mathrm{L}$.

Abbreviations: BUN, blood urea nitrogen; AST, aspartate transaminase; ALT, alanine transaminase; CRP, C-reactive protein.

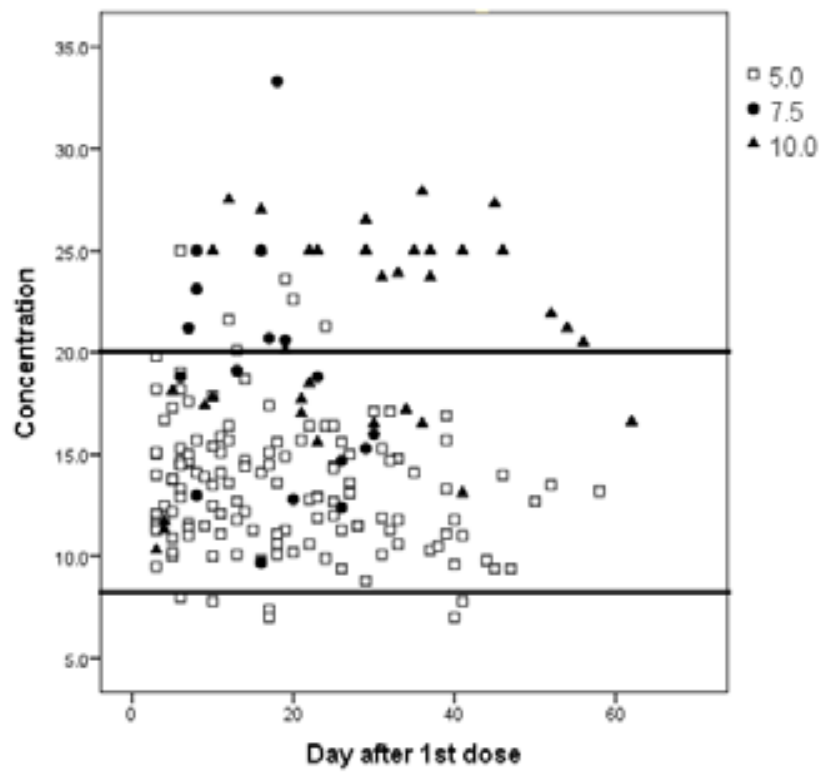

Figure 1. The distribution of serum caffeine levels at the days after 1st dose is shown with different shapes depicting data of different therapeutic doses. 
Table 3. Comparison of Patient Characteristics between Normal and High Concentration Group

\begin{tabular}{lccc}
\hline & $\begin{array}{c}\text { Normal group } \\
(\mathrm{N}=129)\end{array}$ & $\begin{array}{c}\text { High group } \\
(\mathrm{N}=6)\end{array}$ & $P$-value \\
\hline Gestational age (wks) & $28.9 \pm 2.3$ & $28.8 \pm 2.1$ & 0.876 \\
Postconceptional age (wks) & $33.9 \pm 2.3$ & $32.3 \pm 0.9$ & 0.099 \\
Birth weight (g) & $1,212 \pm 366$ & $1,298 \pm 363$ & 0.575 \\
Body weight (g) & $1,784 \pm 466$ & $1,350 \pm 332$ & 0.026 \\
Postnatal age (d) & $35.1 \pm 23.9$ & $25.0 \pm 12.9$ & 0.308 \\
Apgar score - 1 min & $3.89 \pm 1.38$ & $4.83 \pm 0.41$ & 0.098 \\
Apgar score - 5 min & $6.00 \pm 1.34$ & $6.67 \pm 0.82$ & 0.230 \\
Ventilator care & $22.9 \pm 29.0$ & $34.3 \pm 34.7$ & 0.318 \\
Oxygen support & $49.0 \pm 30.0$ & $37.0 \pm 6.7$ & 0.331 \\
Measurement after n dose & $15.9 \pm 25.1$ & $12.3 \pm 4.4$ & 0.729 \\
BUN (mg/dL) & $7.1 \pm 5.8$ & $10.8 \pm 11.9$ & 0.148 \\
Creatinine (mg/dL) & $0.37 \pm 0.28$ & $0.74 \pm 1.21$ & 0.019 \\
AST (IU/L) & $28.8 \pm 34.0$ & $32.0 \pm 10.9$ & 0.817 \\
Albumin (g/dL) & $3.14 \pm 0.59$ & $3.22 \pm 0.25$ & 0.748 \\
CRP (mg/L) (normal 0-8) & $2.08 \pm 4.32$ & $0.48 \pm 0.19$ & 0.368
\end{tabular}

Data are expressed Mean \pm SD.

Normal range of CRP is $0-8 \mathrm{mg} / \mathrm{L}$.

Abbreviations: BUN, blood urea nitrogen; AST, aspartate transaminase; CRP, C-reactive protein.

Table 4. Multiple Linear Regression Analysis

\begin{tabular}{lcc}
\hline & Beta & $P$-value \\
\hline Gestational age (wks) & 2.495 & 0.149 \\
Postconceptional age (wks) & -2.946 & 0.093 \\
Body weight (g) & -0.371 & 0.024 \\
Apgar score - lmin & -0.015 & 0.885 \\
BUN (mg/dL) & -0.139 & 0.286 \\
Creatinine (mg/dL) & 0.123 & 0.322 \\
Albumin (g/dL) & -0.206 & 0.026 \\
CRP (mg/L) & -0.026 & 0.769 \\
\hline
\end{tabular}

$\mathrm{F}=2.794, P$-value $=0.008$.

Abbreviations: BUN, blood urea nitrogen; CRP, C-reactive protein.

and half-life (22.6 h). Based on these results, a clearance formula for each population was obtained using the following formula: typical clearance $=0.0293 \times(\mathrm{BW} / 70)^{1.33}$. The clearance was significantly correlated with the current weight, and the model was fitted with an OFV of 885.53 (Table 4).

\section{DISCUSSION}

For over 20 years, caffeine has been successfully used to treat apnea in premature neonates ${ }^{1,10)}$. However, limited data on caffeine PK parameters and dosage schedules in premature neonates are available. The population approach is an effective way to determine the safety and efficacy of caffeine, but has not been previously applied to Korean neonates. This study is the first to investigate the population PK of caffeine in Korean preterm neonates.

The clearance and half-life of caffeine change rapidly in the postnatal period, and it may be necessary to adjust dosage regimens as neonates grow older. Controversies exist among various neonatal intensive care units in terms of dosage regimen, time of initiation, duration of therapy, and value of TDM. One recommended regimen reduces the dosage interval from once daily for neonates younger than a month to every 12, 8, or 6 hours for infants aged 1 to 2 months, 2 to 4 months, or 4 months and older, respectively ${ }^{11)}$. In a previous study, the recommended loading dose of caffeine citrate was $20 \mathrm{mg} / \mathrm{kg}$ and the maintenance treatment (5 to $10 \mathrm{mg} / \mathrm{kg}$ once a day) should be administered orally or by intravenous infusion. In this study, the dosage interval was not adjusted based on postnatal age. Instead, a loading dose of $20 \mathrm{mg} / \mathrm{kg}$ caffeine was administered, followed by a maintenance dose of $5 \mathrm{mg} / \mathrm{kg}$ administered every 24 hours, and increased to $10 \mathrm{mg} / \mathrm{kg}$ based on the symptoms and serum caffeine levels.

Caffeine is metabolized in the liver by CYP1A $2^{12)}$. The metabolism of caffeine is limited in neonates because of their immature hepatic enzyme system; approximately $86 \%$ of caffeine dose is excreted unchanged in the urine ${ }^{13,14)}$. Therefore, physiological variables related to renal function would influence caffeine clearance in newborns. Several other factors including genetic variation in hepatic metabolic enzymes and caffeine receptors may also contribute to the variability in pharmacodynamic responses ${ }^{15-17)}$. This study included neonates with normal AST, ALT, BUN, and creatinine levels, and excluded newborns with kidney or liver disease.

The serum concentration of caffeine should be monitored periodically, especially in critically ill neonates with unexplained adverse effects, and the therapeutic range is $8-20 \mathrm{mg} / \mathrm{L}^{18,19)}$. In a study of neonates with GA of 27.6 weeks, groups that maintained caffeine dosing at 5 and $20 \mathrm{mg} / \mathrm{kg}$ had a mean serum caffeine concentration of $14.7 \mu \mathrm{g} / \mathrm{mL}(4.8-25.1 \mu \mathrm{g} / \mathrm{mL})$ and $47.4 \mu \mathrm{g} / \mathrm{mL}$ $(18.9-79.8 \mu \mathrm{g} / \mathrm{mL})$, respectively ${ }^{2}$. In another study, the mean serum caffeine levels of 75 preterm neonates were $11.8 \mu \mathrm{g} /$ $\mathrm{mL}(4.75-26.1 \mu \mathrm{g} / \mathrm{mL})$, with less than $4 \%>20 \mu \mathrm{g} / \mathrm{mL}^{20)}$. In this 
study, based on neonates at 29.5 weeks GA, the mean serum concentration was $15.48 \mu \mathrm{g} / \mathrm{mL}(7.8-33.0 \mu \mathrm{g} / \mathrm{mL})$. Among the neonates receiving maintenance caffeine doses of 5 and $10 \mathrm{mg} /$ $\mathrm{kg}, 6$ (3\%) and 23 (12\%) showed serum caffeine levels >20 $\mu \mathrm{g} /$ $\mathrm{mL}$. The blood concentration of caffeine varies, and careful monitoring for toxicity is required. The serum concentration of caffeine tends to be high in underweight neonates, and extra caution is required with this population.

Caffeine toxicity has not been reported at the therapeutic plasma concentrations required to treat apnea of prematurity. Caffeine is a CNS and cardiovascular stimulant and has been associated with irritability, restlessness, jitteriness, tachycardia, and other cardiovascular effects ${ }^{4)}$. Other side effects are feeding intolerance, increased urine output, and necrotizing enterocolitis $^{21)}$.

Serum caffeine levels $>50 \mu \mathrm{g} / \mathrm{mL}$ have been associated with fever, tachypnea, hypertonia, vomiting, hyperglycemia, elevated BUN, leukocytosis, seizures, and other symptoms ${ }^{4,22)}$. In another study, the heart rate and caffeine serum concentrations were significantly correlated $(P<0.05)$, which is consistent with the increased probability of tachycardia with increased caffeine serum concentration $^{23)}$. TDM monitoring should be considered in critically ill neonates with unexplained adverse effects such as tachycardia therefore it has been done in our institution and since the highest serum caffeine concentration was $33 \mu \mathrm{g} / \mathrm{mL}$ in our study, it was not possible to assess side effects at levels greater than $50 \mu \mathrm{g} / \mathrm{mL}$. In this study, no definite adverse effects were found. Moreover, no cases of serum caffeine levels $>50 \mu \mathrm{g} /$ $\mathrm{mL}$ were recorded, and with constant observation, the dosage proved to be safe.

It is widely known that drug disposition in premature neonates can differ markedly from that in older children and adults ${ }^{19,24)}$. The half-life of caffeine in preterm neonates ( $<33$ weeks GA) was 87 hours, compared to 72-96 hours in the term neonate group $^{20)}$. The elimination of caffeine was severely suppressed in premature neonates but increased nonlinearly after birth up to 6 weeks of age, and reached adult values at approximately 60 weeks postmenstrual age ${ }^{2)}$. The caffeine half-life observed for neonates in this study was shorter than that reported in other studies, which may have been caused by differences in the postnatal days.

Individual estimates of clearance were obtained using the population estimates and a post hoc Bayesian analysis of the individual concentration measurements. The mean cl- earance estimate was $1.8 \mathrm{~mL} / \mathrm{h} / \mathrm{kg}$, which was lower than the average clearance values $(7.9-8.9 \mathrm{~mL} / \mathrm{h} / \mathrm{kg})$ reported by other studies $^{20,25,26)}$. The estimate of the population mean volume of distribution of caffeine $(748 \mathrm{~mL} / \mathrm{kg})$ is similar to values reported by other studies $(911 \mathrm{~mL} / \mathrm{kg})^{2,27)}$. For estimation of the parameters in the preterm neonate population, the NONMEM program was used to assess the PK profile information for caffeine. The assessment showed that postnatal age, regardless of current weight, was the continual variable that yielded the best adjustment of data in a clearance model. Thomson et al. ${ }^{27)}$ modeled clearance as a simple function of current weight and postnatal age without the effect of any other covariate. Based on the analysis of the population PK of premature Korean neonates, the caffeine clearance was proven to be affected by current BW, in accordance with previous results. Using the proportional error model for the random effects parameters, this study showed an OFV of 885.53. The interindividual variability of clearance was $14.87 \%$, and the residual variability was $18.44 \%$. Moreover, the estimated values for the final parameters presented a typical pattern with a precision within acceptable limits for both the fixed and random effects parameters $(<20 \text { and }<50 \% \text {, respectively })^{28)}$. The limitations of this study are the small sample size and insufficient variation in sampling times. In addition, the study was retrospectively conducted, and the toxicity symptoms could not be verified.

A comparison of the PK data of Koreans with that of other ethnicities revealed similarities in the clearance and volume of distribution values. The neonates had lower BWs than normal, which may have increased the caffeine serum levels. Therefore, the caffeine blood levels should be carefully monitored only in neonates with low BW who have apnea or signs of toxicity.

\section{REFERENCES}

1) Kreutzer $K$, Bassler D. Caffeine for apnea of prematurity: a neonatal success story. Neonatology 2014;105:332-6.

2) Charles BG, Townsend SR, Steer PA, Flenady VJ, Gray PH, Shearman A. Caffeine citrate treatment for extremely premature infants with apnea: population pharmacokinetics, absolute bioavailability, and implications for therapeutic drug monitoring. Ther Drug Monit 2008;30:709-16.

3) Steer P, Flenady V, Shearman A, Charles B, Gray PH, Henderson-Smart D, et al. High dose caffeine citrate for extubation of preterm infants: a randomised controlled trial. Arch Dis Child 
Fetal Neonatal Ed 2004;89:F499-503.

4) Comer AM, Perry CM, Figgitt DP. Caffeine citrate: a review of its use in apnoea of prematurity. Paediatr Drugs 2001;3:61-79.

5) Schmidt B, Roberts RS, Davis P, Doyle LW, Barrington KJ, Ohlsson A, et al. Long-term effects of caffeine therapy for apnea of prematurity. N Engl J Med 2007;357:1893-902.

6) Anderson BJ, Gunn TR, Holford NH, Johnson R. Caffeine overdose in a premature infant: clinical course and pharmacokinetics. Anaesth Intensive Care 1999;27:307-11.

7) van den Anker JN, Jongejan HT, Sauer PJ. Severe caffeine intoxication in a preterm neonate. Eur J Pediatr 1992;151:466-7.

8) Henderson-Smart DJ, Steer PA. Caffeine versus theophylline for apnea in preterm infants. Cochrane Database Syst Rev 2010:CD000273. doi: 10.1002/14651858.CD000273.pub2.

9) Ulanovsky I, Haleluya NS, Blazer S, Weissman A. The effects of caffeine on heart rate variability in newborns with apnea of prematurity. J Perinatol 2014;34:620-3.

10) Finer NN, Higgins R, Kattwinkel J, Martin RJ. Summary proceedings from the apnea-of-prematurity group. Pediatrics 2006;117:S47-51.

11) Pons G, Carrier O, Richard MO, Rey E, d'Athis P, Moran C, et al. Developmental changes of caffeine elimination in infancy. Dev Pharmacol Ther 1988;11:258-64.

12) Perera V, Gross AS, Forrest A, Landersdorfer CB, Xu H, AitOudhia S, et al. A pharmacometric approach to investigate the impact of methylxanthine abstinence and caffeine consumption on CYP1A2 activity. Drug Metab Dispos 2013;41:1957-66.

13) De Carolis MP, Romagnoli C, Muzii U, Tortorolo G, Chiarotti M, De Giovanni N, et al. Pharmacokinetic aspects of caffeine in premature infants. Dev Pharmacol Ther 1991;16:117-22.

14) Gal P. Caffeine therapeutic drug monitoring is necessary and cost-effective. J Pediatr Pharmacol Ther 2007;12:212-5.

15) Bloch-Salisbury E, Hall MH, Sharma P, Boyd T, Bednarek F, Paydarfar D. Heritability of apnea of prematurity: a retrospective twin study. Pediatrics 2010;126:779-87.

16) Kumral A, Tuzun F, Yesilirmak DC, Duman N, Ozkan H. Genetic basis of apnoea of prematurity and caffeine treatment response: role of adenosine receptor polymorphisms: genetic basis of apnoea of prematurity. Acta Paediatr 2012;101:299303.
17) Pacifici GM. Clinical pharmacology of caffeine citrate in preterm infants. Med express 2014;1:243-50.

18) Aranda JV, Turmen T. Methylxanthines in apnea of prematurity. Clin Perinatol 1979;6:87-108.

19) Parat S, Mhanna MJ. Respiratory management of extremely low birth weight infants: survey of neonatal specialists. World J Pediatr 2016;12:314-9.

20) Falcao AC, Fernandez de Gatta MM, Delgado Iribarnegaray MF, Santos Buelga D, Garcia MJ, Dominguez-Gil A, et al. Population pharmacokinetics of caffeine in premature neonates. Eur J Clin Pharmacol 1997;52:211-7.

21) Mueni E, Opiyo N, English M. Caffeine for the management of apnea in preterm infants. Int Health 2009;1:190-5.

22) Schmidt B, Roberts RS, Davis P, Doyle LW, Barrington KJ, Ohlsson A, et al. Caffeine therapy for apnea of prematurity. $\mathrm{N}$ Engl J Med 2006;354:2112-21.

23) Yu T, Balch AH, Ward RM, Korgenski EK, Sherwin CM. Incorporating pharmacodynamic considerations into caffeine therapeutic drug monitoring in preterm neonates. BMC Pharmacol Toxicol 2016;17:22.

24) Kearns GL, Abdel-Rahman SM, Alander SW, Blowey DL, Leeder JS, Kauffman RE. Developmental pharmacology--drug disposition, action, and therapy in infants and children. $\mathrm{N}$ Engl J Med 2003;349:1157-67.

25) Gorodischer R, Karplus M. Pharmacokinetic aspects of caffeine in premature infants with apnoea. Eur J Clin Pharmacol 1982; 22:47-52.

26) Aranda JV, Cook CE, Gorman W, Collinge JM, Loughnan PM, Outerbridge EW, et al. Pharmacokinetic profile of caffeine in the premature newborn infant with apnea. J Pediatr 1979;94: 663-8.

27) Thomson AH, Kerr S, Wright S. Population pharmacokinetics of caffeine in neonates and young infants. Ther Drug Monit 1996;18:245-53.

28) Le Guennec JC, Billon B, Pare C. Maturational changes of caffeine concentrations and disposition in infancy during maintenance therapy for apnea of prematurity: influence of gestational age, hepatic disease, and breast-feeding. Pediatrics 1985; 76:834-40. 